\title{
Investigating E-Servicescape Influence to Customer Response in Digital Islamic Banking
}

\author{
Prima Andriani \\ Universitas Gadjah Mada, Indonesia, primaandriani@mail.ugm.ac.id \\ Noni Setyorini \\ Universitas PGRI Semarang, Indonesia \\ Corresponding email: nonisetyorini@upgris.ac.id \\ Ahmad Hafiyyan Shibghatalloh \\ Universitas Diponegoro, Indonesia, ahmadhafiyyan@students.undip.ac.id
}

Article History

Received: November $11^{\text {th }}, 2020$ Revised: January $7^{\text {th }}, 2021$ Accepted: January $18^{\text {th }}, 2021$

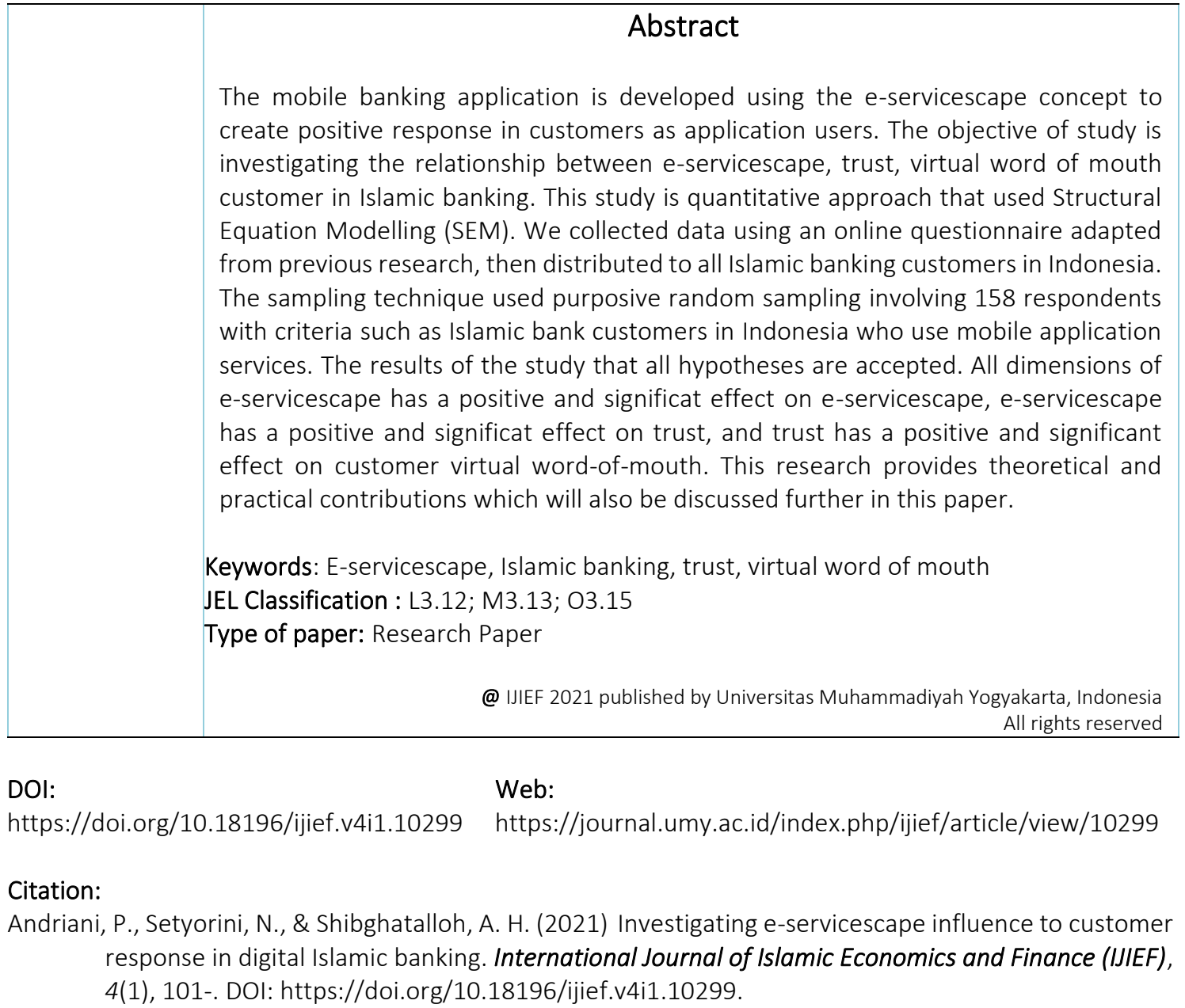


Andriani, Setyorini, \& Shibghatalloh | Investigating E-Servicescape Influence to Customer Response in Digital Islamic Banking

\section{Introduction}

\subsection{Background}

The development of banking services via the internet has become increasingly prevalent in line with the growth of increasingly sophisticated information technology. Product innovation factors and technological developments are an integral part of the development of the banking industry to improve service quality so that it becomes more accessible and efficient. This is driven by a shift in customer behavior that has begun to involve the role of technology in various activities including financial activities. The presence of technology removes space and time restrictions on the relationship between banks and customers so that banks can reach customers more closely, quickly, and easily. This change requires companies to integrate several business functions and even reach out to external partners in creating and providing positive experiences for customers (Baidhowi, 2018).

Nowdays, as a bank's effort to reach and serve customers in a more concrete manner, internet-based service innovation is a breakthrough that continues to be developed in the banking sector. One that has been developed a lot is electronic channel services. This service is provided by various banks that have physical official offices, but also create an internet-based website and provide services through applications that can be accessed using cell phones. In addition, the electronic channel is used as a strategic and differentiation channel to offer low-cost financial service products such as credit cards. One form of electronic services currently being intensified by banks is the development of mobile banking applications. Mobile banking is part of the top priority of online banking services as a modern banking strategy (Tam \& Oliveira, 2016). Cellular banking is a form of electronic transactions that makes it easy for customers to transact via mobile personal platforms (Wessels \& Drennan, 2010). Transaction mode using mobile banking is becoming common among the public because it makes easier for customers to check account balances and transaction history, transfer money, pay bills, trade securities, manage portfolios, pay insurance and others (Baptista \& Oliveira, 2016).

The development of mobile application-based digital services in academia has been widely researched. One of the topics discussed and developed by academics and practitioners in the field of marketing is e-servicescape. Servicescape was developed by (Bitner, 1992) which describes the ambient conditions, layout and functionality, as well as signs, symbols, and artifacts from the service delivery process of a company. The previous servicescape concept was intended for offline processes, but over time this concept was 
Andriani, Setyorini, \& Shibghatalloh Investigating E-Servicescape Influence to Customer Response in Digital Islamic Banking

updated to e-servicescape by Harris and Goode (2010) to reach the online service delivery process.

The concept of e-servicescape is not only relevant to be developed as an online marketing strategy such as an online shopping application, but also relevant to be developed for mobile banking applications, as research conducted by Sahoo and Pillai (2017). Mobile banking application development should indeed pay attention to the three dimensions contained in the e-servicescape concept to create value that can be felt by customers as application users. Value creation has become a popular field in marketing and industrial research related to consumer behavior so it is an important concern for practitioners and academics (Heinonen, 2004).

All kinds of digital service development in Islamic banking should pay attention to the value developed for later transfer to customers. If a service is considered valuable by a customer, the customer's response to the bank will be even more positive. One of the values that is important to develop is customer trust. The response shown by the user is an important indicator as an evaluation material and service development which should be continuously improved by the company. User responses will usually be manifested in the form of attitudes and implemented in the form of behavior. If users feel that they are benefited, then they will show a favorable attitude for the company. This is a big concern for the company to satisfy users.

This phenomenon can be described in the theory of Stimulus-OrganismResponse (SOR) developed by Russell and Mehrebian in 1974. SOR theory has provided a model for studying customer transaction processes (Turley \& Milliman, 2000). Based on previous research, SOR theory has supported research using the e-servicescape dimension (Kawaf \& Tagg, 2012). The SOR theory is a theory that can be used to evaluate the development of electronic channel services to improve the experience of sharia banking customers. Therefore, this study will examine the process of using the electronic channel of banking customers using this theory.

Objective

The objectives of this study was to determine perceived of customer related to e-servicescape, trust, and virtual word of mouth. Our motivation in this study is expanding research related to financial technology in the Islamic banking sector and provide advice to practitioners to improve digital innovation in banking services to compete in an increasingly touchless industrial era. 
Andriani, Setyorini, \& Shibghatalloh Investigating E-Servicescape Influence to Customer Response in Digital Islamic Banking

This paper begins with a review of the phenomena of the development of digital innovation in the banking sector, especially Islamic banking in Indonesia. Furthermore, simplification of the digital Islamic banking phenomenon into a model that is explained using SOR theory to make it easier to understand customer perceptions regarding the role of banking applications. The constructs used in this study are derived from previous studies as in the literature study. This study analyzes a conceptual model that has been developed using the SEM PLS method which is tested using the SMART PLS tool. The discussion of results and discussion is presented further in this paper. This research is closed with the conclusion of the research results along with the limitations and future research agenda.

\section{Literature Review}

\subsection{Background Theory}

\subsubsection{Stimulus-Organism-Response}

The Stimulus Organism Response (SOR) theory is a theory used to explain that the environment is a stimulus (S) which consists of a set of signs. After getting the stimulus (S) from this sign, a person's internal evaluation $(O)$ appears. If evaluation $(\mathrm{O})$ has been carried out then humans will generate a response ( $R$ ) (Mehrabian \& Russell, 1974). The SOR model shows that the user's emotions are an important part of responding to stimuli from the environment (Brown, Mowen, Donavan, \& Licata, 1996). This model also shows that conscious and unconscious perceptions and environmental interpretations affect what a person feels (Donovan \& Rossiter, 1982). Based on the SOR theory, in previous studies the reputation and quality of electronic channel applications function as environmental stimuli, after which cognition and emotions function as organisms, and purchase intention functions as a response.

\subsubsection{E-Servicescape}

Dailey (2004) defines e-servicescape as an internet-based web environment design to create a positive influence on users to increase favorable responses. Harris and Goode (2010) developed the e-servicescape concept by dividing it into three dimensions, namely layout and functionality, aesthetic appeal, and financial security. In online applications, aesthetic appeal refers to the ambient conditions of the application and the extent to which the user packs the servicescape concept as attractive (Harris \& Goode, 2010). Online layout refers to the arrangement of colors and designs, the organization of functions, structure, and adaptability of internet-based pages, while functionality refers to the extent to which something can accommodate services according to the 
Andriani, Setyorini, \& Shibghatalloh | Investigating E-Servicescape Influence to Customer Response in Digital Islamic Banking

purpose of creating an application (Bitner, 1992). Online financial security is intended to facilitate a secure payment process in accordance with applicable policies (Harris \& Goode, 2010).

The internet site as an e-servicescape is evidence of a change in the business world which is expected to be a strategy to increase the success of a business (Lai, Chong, Ismail, \& Tong, 2014). Previous research has proven that consumer page trust and purchase intentions are influenced by eservicescape (Harris \& Goode, 2010), trust (Papadopoulou, Andreou, Kanellis, \& Martakos, 2001), as well as customer cognitive and affective responses during transactions (Eroglu, Machleit, \& Davis, 2003).

\subsubsection{Trust}

Perceived of trust in $\mathrm{m}$-banking is defined as consumer trust that electronic payment transactions will be processed according to their expectations (Tsiakis \& Sthephanides, 2005). Consumers can make rational decisions based on knowledge and analysis based on feelings of trust and distrust. Trust is the perception of consumers because they expect higher profits by using a product, while consumer distrust is their effort to reduce potential losses (Kousaridas, Parissis, \& Apostolopoulos, 2008). The trust issues required for electronic payment systems to be used as a general medium of financial transactions are: identification, authentication, accountability, authorization, and availability (Tsiakis \& Sthephanides, 2005). Some payment systems such as those on mobile phones can provide independence in time and place, remote payments, availability, and queue avoidance.

\subsubsection{Virtual Word of Mouth}

Word of mouth is a tradition where this mode of communication was carried out at the earliest times (Mayzlin, Dover, \& Chevalier, 2014).Katz and Lazarsfeld provided the earliest explanation in the late 1960s, describing it as an important means of exchanging product-related information among consumers (Katz \& Lazarsfeld, 1966). Trusov, Bucklin, and Pauwels (2008) explain that word of mouth has the potential to shape consumer behavior towards a product or service, this is powerful tool for marketing. The advancement of information technology has made the use of the internet and social media very widespread, thus affecting the mode of communication preferred by people (Chan \& Ngai, 2011). Electronic word of mouth (e-WOM) or virtual word of mouth has become the most common medium used to share opinions and reviews about various products and services available in the market (Cheung \& Thadani, 2012). E-WOM is in the form of statements made by potential customers, actual customers, or former customers about a product or company that is available to many people and institutions via the Internet which contains positive or negative sentences. 
Andriani, Setyorini, \& Shibghatalloh | Investigating E-Servicescape Influence to Customer Response in Digital Islamic Banking

\subsection{Previous Studies}

The e-servicescape research conducted by (Harris \& Goode, 2010) examined the dimensions of e-servicescape consisting of aesthetic attractiveness, layout and functionality, and financial security on trust on websites, then tested the relationship of trust in the website to purchase intention. (Harris \& Goode, 2010) examined e-servicescape in the e-commerce context using an online survey method for data collection. The data processing method used a quantitative approach with SEM. The results of their study stated that all hypotheses are accepted where the e-servicescape dimensions have positive effect on trust in the website and trust in the website has a positive effect on purchase intention.

E-servicescape research is not only researched using an empirical research approach but also a literature research approach, as was done by (Mari \& Poggesi, 2013) who researched with a qualitative approach. The research aims to fill the gap with a systematic literature review. Their study reviewed 188 papers indexed in sixteen journals, the majority of which were indexed in Q1. The results of their literature study contribute to deep understanding of the relationship between customer behavior and interpreting servicescapes more specifically.

Empirical research on e-servicescape in the context of banking has been conducted by (Sahoo \& Pillai, 2017). Their research examines the context of conventional banking only. The purpose of their research is to examine the effect of servicescape in the context of mobile banking on attitudes and customer engagement as mobile banking users. (Sahoo \& Pillai, 2017) use online survey techniques for data collection methods. (Sahoo \& Pillai, 2017) use SEM to analyze conceptual models and test their hypotheses. Their research results indicate that e-servicescape is a strong predictor of customer attitudes towards the use of mobile banking, which in turn affects customer engagement. In addition, other findings indicate that customer attitudes mediate e-servicescape on customer engagement.

Empirical research on e-servicescape in the field of e-commerce has been conducted by (Tankovic \& Benazic, 2018). The research objective of them is to examine the relationship between e-servicescape dimensions on perceived value and to examine perceived value on customer loyalty. Data collection used online surveys with criteria such as customers who made online purchases at least in the last six months. Data processing using SEM. Their research results state that customer perceptions of e-servicescape positively affect the perceived value and loyalty of e-shopping. Specifically, this study finds that the dimensions of e-servicescape are layout and functionality and financial security as the most prominent attributes in determining the perceived value of e-shopping that affects loyalty. 
Andriani, Setyorini, \& Shibghatalloh Investigating E-Servicescape Influence to Customer Response in Digital Islamic Banking

The latest e-servicescape research was carried out by (Tran \& Strutton, 2020) in the field of e-commerce. Their research objectives are to examine the dimensions of e-servicescape on trust, to examine trust on E-WOM intention and customer loyalty. In addition, they compared the results of the influence test between consumers who receive messages via social media posts with email recipients. Their research used an online survey then processed using SEM. Their results showed that customer reviews play an integral role in eservicescape construction, that e-servicescape has a positive impact on trust and then trust positively affects E-WOM and customer loyalty. Two groups of consumers are compared, and the results show the difference between consumers who receive messages via social media posts and recipients of email.

\subsection{Conceptual Framework}

Based on the SOR theory, the stimulus is an organism's external environment that will influence the internal reactions of consumers. These reactions, in turn, drive external behavioral responses among organisms (Mehrabian \& Russell, 1974). The response of these internal organisms includes both affective and cognitive elements and acts as stimulation. SOR theory has supported the investigation of the dimensions of the e-servicescape atmosphere (specifically, website and service factors) on consumer behavior in the e-tailer environment ( $\mathrm{Ha} \&$ Lennon, 2010) and co-creation in forming online brand communities (Kamboj, Sarmah, Gupta, \& Dwivedi, 2018). Website reputation and quality serve as environmental stimuli. Therefore, the characteristics of the application of Islamic banking electronic channels (aesthetic appeal, design originality, entertainment value, usability, information relevance, interactivity, ease of transaction and application security) can stimulate and influence consumers to make transactions (Tran $\&$ Strutton, 2020). Based on these theoretical reasons and previous reviews, the hypothesis we propose is as follows:

Hypothesis 1:

(a) E-servicescape has a positive effect on aesthetic appeal

(b) E-servicescape has a positive effect on design originality

(c) E-servicescape has a positive effect on entertainment value

(d) E-servicescape has a positive effect on usability

(e) E-servicescape has a positive effect on the relevance of information

(f) E-servicescape has a positive effect on interactivity

(g) E-servicescape has a positive effect on ease of transactions

(h) E-servicescape has a positive effect on application security 
Andriani, Setyorini, \& Shibghatalloh Investigating E-Servicescape Influence to Customer Response in Digital Islamic Banking

In SOR Theory, cognition and emotions function as organisms (Tran \& Strutton, 2020). Organisms are a form of response based on the stimuli that have been given. The message (stimulus) given by the communicator to the communicant (organism) can be accepted or rejected by the communicant. If the communicant refuses a given stimulus, it means that the stimulus is less effective. However, if the stimulus is received, it will give rise to a cognition and emotion. E-servicescape serves as a stimulus for trust in mobile banking customers. The concept of e-servicescape that is adapted to the development of digital media can be used to increase customer trust so that it will create positive responses. If the better the concept of e-servicescape in fulfilling customer desires, the higher customer trust in e-servicescape will be. Based on these theoretical reasons and previous reviews, the hypothesis we propose is as follows:

Hypothesis 2: E-servicescape has a positive effect on trust

Based on the SOR Theory after consumers receive stimuli and process the stimulus they receive, this will lead to attitudes and actions to be taken by consumers (Effendy, 2003). If based on the stimuli provided through eservicescape it is successful, it will raise a perception of trust in the minds of consumers. If consumers already have the trust, they will make an evaluation based on their experience using e-servicescape. Evaluation can be in the form of customer reviews themselves (E-WOM communication). Recipients perceive customer reviews as more credible than messages conveyed through traditional marketing media. This is because $85 \%$ of consumers trust online reviews as well as personal recommendations (Nazlan, Tanford, \& Montgomery, 2018). The usefulness of information and the credibility of sources both have a positive influence on online opinion adoption (Cheung, Lee, \& Rabjohn, 2008; Ismagilova, Slade, Rana, \& Dwivedi, 2020). Based on these theoretical reasons and previous reviews, the hypothesis we propose is as follows:

Hypothesis 3: Trust has a positive effect on virtual word of mouth

\section{Methodology}

\subsection{Data}

The type of data used in this study is cross-sectional in which the type of data is used to capture a phenomenon at a certain time (Couper \& Schindler, 2014). The sample collection technique used was purposive random sampling by determining certain criteria as respondents. The criteria for respondents determined by the research team are customers of Islamic banks in Indonesia who use mobile banking application services. The data was collected using an 
Andriani, Setyorini, \& Shibghatalloh | Investigating E-Servicescape Influence to Customer Response in Digital Islamic Banking

online survey involving 158 respondents who are customers of Islamic banks in Indonesia. If the sample size is $<250$ then PLS-SEM has no problem in the process of identifying the relationship between theoretical constructs (Reinartz et al., 2009) and has no special requirements tied to the distribution of manifest variables because it is a non-parameter method so we are using 158 respondents who are customers of Islamic banks in Indonesia as respondent. The format of the questionnaire chosen was a closed questionnaire by providing answers so that respondents were asked to choose between a series of answers given by the researcher (Neuman, 2016). The measurement scale used in the questionnaire is a likert scale of 1 (strongly disagree) to 5 (strongly agree).

The measurement indicators for the e-servicescape construct were adapted from Harris and Goode (2010) as research conducted by Tankovic and Benazic, (2018); Tran and Strutton (2020). E-servicescape is a construct with a reflective type. One example of an indicator for the e-servicescape construct used is "The appearance of the mobile banking application is visually attractive". The e-servicescape construct is a construct with several dimensions, namely visual appeal, entertainment value, design originality, usability, information relevance, customization, interactivity, application security, and ease of payment. However, in this study, we did not use the customization dimension because the mobile banking application was not custom created for individual.

The measurement indicator for the trust construct is the consumer's belief that electronic payment transactions will be processed according to their expectations (Mallat, 2007). An example of an indicator used to test the trust variable is "I believe making transactions via the mobile banking application is safe". The measurement indicators for the virtual word-of-mouth construct were adapted from (Hennig-Thurau, Gwinner, Walsh, \& Gremler, 2004; Hung \& Li, 2007) as research conducted by Tsao and Hsieh (2012). One example of an indicator for the virtual word-of-mouth construct used is "I am willing to tell other internet users that I am a customer of a company's mobile banking application".

\subsection{Model Development}

This study is explained more comprehensively using SOR theory as previous studies that examined e-servicescape such as those conducted by (Sahoo \& Pillai, 2017). In this research, e-servicescape functions as an environmental stimulus; trust as an organism; and virtual word of mouth as a response. A reflective model is used in this study to explain e-servicescape. The reflective indicator model is a condition in which indicators that can reflect latent 
Andriani, Setyorini, \& Shibghatalloh | Investigating E-Servicescape Influence to Customer Response in Digital Islamic Banking

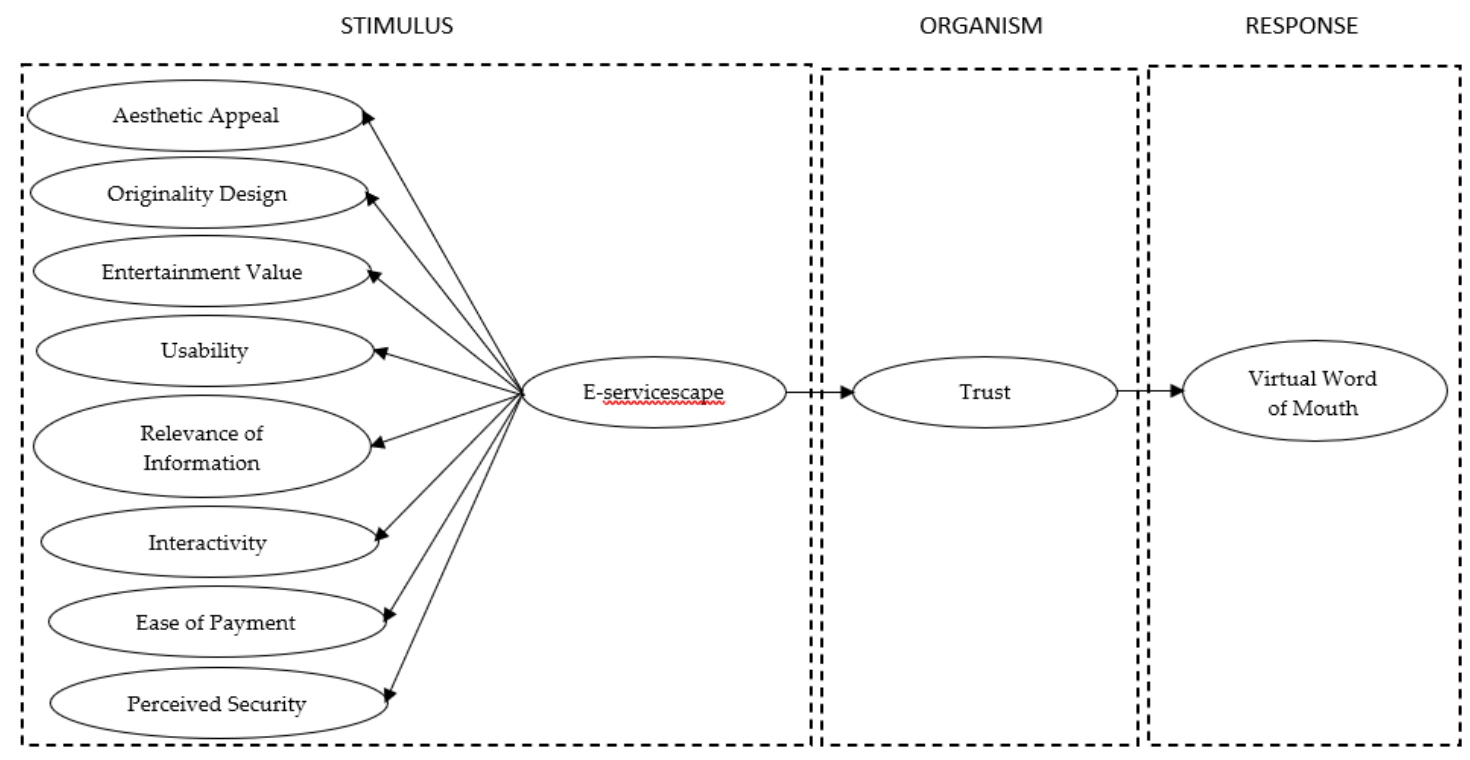

Figure 1. Research Model

variables, or in other words, latent variables is a reflection of the indicators. In the reflective indicator model mathematically places the indicator as if it is influenced by latent variables, but the independent variables do not have data. The use of a reflective model in this study is based on research proposed by Harris and Goode (2010) which formulated the concept of e-servicescape with a reflective model consisting of dimensions that reflect e-servicescape (usability, original design, entertainment value, aestethic appeal, etc). This study proposes a model as described in Figure 1 Research Model.

\subsection{Method}

The collected data were processed using the partial least squares (PLS) to analyze structural equations (SEM). SmartPLS 3 software was used for data analysis (Ringle et al., 2015). This research will use the second order confirmatory factor analysis method. So, Data were analyzed in two steps. First, make a second order modeling then test the goodness of fit model. The goodness of fit test is done by using validity and reliability tests to identify the feasibility of the questionnaire used for data collection. Especially in testing the servicescape variable is measured based on the dimensions that reflect it. The validity test refers to the truth or accuracy which informs that the indicator is the right fit with the operational definition of a construct that can be measured by the indicator (Neuman, 2016). The validity test is seen from the Average Variance Extracted (AVE) value where the construct is said to be valid if the AVE value is $>0.5$. The reliability test reflects the internal consistency of the measuring instrument (Hair et al., 2014). The reliability test 
Andriani, Setyorini, \& Shibghatalloh Investigating E-Servicescape Influence to Customer Response in Digital Islamic Banking

is viewed from the Cronbach Alpha (CA) or Composite Reliability (CR) value, which constructs are reliable if the CA or CR value is $\geq 0.7$.

Second, test the hypothesis according to the proposed model. Parameters in PLS SEM hypothesis testing are the result of t-statistic> 1.96 to support the hypothesis. Meanwhile, if the results of t-statistics $<1.96$ then the hypothesis is not supported. Meanwhile, the effect size and direction of the effect can be seen from the path estimate value (Hair et al, 2014).

\section{Results and Analysis}

\subsection{Results}

This study uses validity and reliability tests to measures the feasibility of the instrument. The validity test consists of the convergent validity test. The discriminant validity test is declared good when the indicator of the construct has the highest loading value in its group or column (Hair et al., 2014). Based on the results of the validity test above, all the results of the convergent validity test showed the AVE value $>0.5$ so that all constructs in the study were declared valid. The results of the validity test are presented in Table 1 Result of Validity Testing.

This study will compare the CR and CA values to choose which one has the highest value, then it will be used as the result of the reliability test. Based on the reliability test results above, all reliability test results show that the Cronbach alpha value exceeds 0.6 so that all constructs in the study are valid and can be used to carry out further testing. The results of the reliability test are presented in Table 2 Result of Reliability Testing.

Table 1. Result of Validity Testing

\begin{tabular}{ccc}
\hline Constructs & AVE Value & Result \\
\hline Aesthetic appeal & 0.752 & Valid \\
Entertainment Value & 0.645 & Valid \\
Originality design & 0.810 & Valid \\
Usability & 0.677 & Valid \\
Relevance Information & 0.838 & Valid \\
Interactivity & 0.690 & Valid \\
Perceived security & 0.773 & Valid \\
Easy of payment & 0.748 & Valid \\
Trust & 0.842 & Valid \\
Virtual word of mouth & 0.797 & Valid \\
\hline Source: Processed data, 2020
\end{tabular}


Andriani, Setyorini, \& Shibghatalloh | Investigating E-Servicescape Influence to Customer Response in Digital Islamic Banking

Table 2. Result of Reliability Testing

\begin{tabular}{cccc}
\hline Constructs & Cronbach Alpha & $\begin{array}{c}\text { Composite } \\
\text { Reliability }\end{array}$ & Result \\
\hline Aesthetic appeal & 0.890 & 0.924 & Reliable \\
Entertainment Value & 0.816 & 0.878 & Reliable \\
Originality design & 0.768 & 0.895 & Reliable \\
Usability & 0.903 & 0.926 & Reliable \\
Relevance Information & 0.961 & 0.969 & Reliable \\
Interactivity & 0.775 & 0.869 & Reliable \\
Perceived security & 0.901 & 0.931 & Reliable \\
Easy of payment & 0.887 & 0.922 & Reliable \\
Trust & 0.906 & 0.941 & Reliable \\
Virtual word of mouth & 0.916 & 0.940 & Reliable \\
\hline
\end{tabular}

Source: Processed data, 2020

Hypothesis $1(\mathrm{a}-\mathrm{h})$ was tested using path analysis. In this test the research team used SEM with a second order. Based on hypothesis $1(a-c)$ it is known that the effect of visual attractiveness on e-servicescape is accepted with path estimate $=0.842$, $t$-value $=11.585$, and $p$-value $<0.05$. Meanwhile, based on hypothesis $1(\mathrm{~d})$ and (e) usefulness it is known that the effect of usability on e-servicescape is accepted with path estimate $=0.884$, $t$-value $=23.787$, and $\mathrm{p}$-value $<0.05$. Furthermore, for hypothesis 1 (f) which represents interactivity it is known that interactivity has an effect on e-servicescape is accepted with path estimate $=0.817, \mathrm{t}$-value $=20.932$, and $\mathrm{p}$-value $<0.05$, while application security is known that the effect of security on e-servicescape is accepted with path estimate $=0.700$, $t$-value $=9,684$, and $p$-value $<0.05$.

Hypothesis 2 states that e-servicescape has an effect on trust is accepted with path estimate $=0.780, t$-value $=11.083$, and $p$-value $<0.05$. Hypothesis 3 states that trust influencing e-WOM is accepted with path estimate $=0.533$, $\mathrm{t}$-value $=6.475$, and $\mathrm{p}$-value $<0.05$. The SMART PLS output display in Figure 2 Hypothesis Testing Results and the Hypothesis Test Result Summary in Table 3 Resume of The Result. 
Andriani, Setyorini, \& Shibghatalloh | Investigating E-Servicescape Influence to Customer Response in Digital Islamic Banking

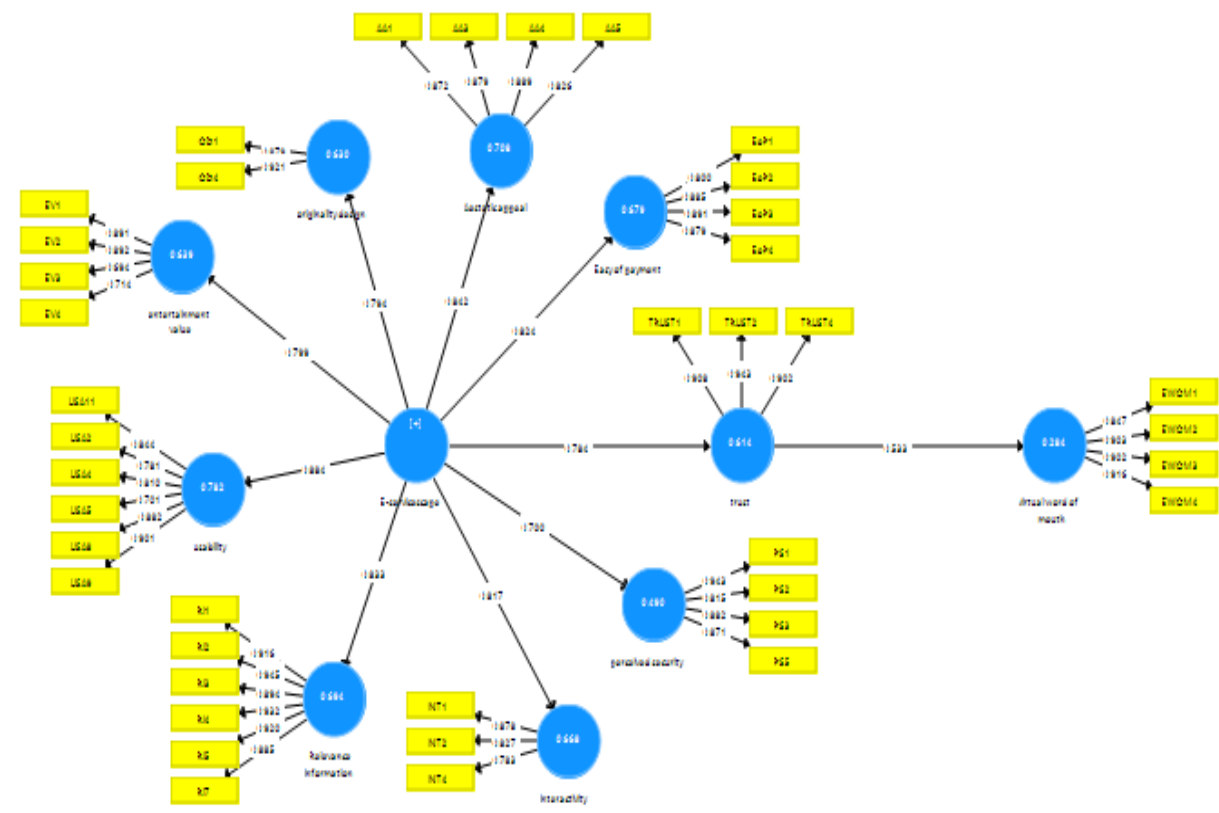

Figure 2. Hypothesis Testing Results

Source: Processed data, 2020

Table 3. Resume of The Result

\begin{tabular}{lcccc}
\hline \multicolumn{1}{c}{ Hypothesis } & Path Estimate & $\mathrm{p}$-value & $\mathrm{t}$-value & Result \\
\hline E-servicescape [? Aesthetic appeal & 0.842 & $<0.05$ & 18.585 & Supported \\
E-servicescape [? Entertainment Value & 0.799 & $<0.05$ & 17.686 & Supported \\
E-servicescape [? Originality design & 0.794 & $<0.05$ & 15.892 & Supported \\
E-servicescape [? Relevance of Information & 0.844 & $<0.05$ & 8.780 & Supported \\
E-servicescape [? Usability & 0.881 & $<0.05$ & 23.787 & Supported \\
E-servicescape [? Interactivity & 0.817 & $<0.05$ & 20.932 & Supported \\
E-servicescape [? Easy of payment & 0.824 & $<0.05$ & 14.771 & Supported \\
E-Sercivescape [? Perceived security & 0.700 & $<0.05$ & 9.684 & Supported \\
E-servicescape [? Trust & 0.784 & $<0.05$ & 12.235 & Supported \\
Trust [ virtual word of mouth & 0.533 & $<0.05$ & 6.435 & Supported \\
E-servicescape -> virtual word of mouth & 0.418 & $<0.05$ & 5.491 & Supported \\
\hline
\end{tabular}

Source: Processed data, 2020

\subsection{Analysis}

Electronic channels are an innovation in banking services where there are multi-faceted, intangible services and innovative service delivery media (Rao \& Troshani, 2007). Researchers have agreed that among various electronicbased self-services, mobile banking applications are a useful platform for digital banking and other financial services (Moser, 2015; Wessels \& Drennan, 2010). Given the importance of e-servicescape, previous studies on eservicescape have analyzed the role of content and features of mobile banking applications in customer responses (Akturan \& Tezcan, 2012). 
Andriani, Setyorini, \& Shibghatalloh | Investigating E-Servicescape Influence to Customer Response in Digital Islamic Banking

The results of this study support Harris and Goode (2010) that aesthetics, usability, and financial security play an important role in determining customer behavior and can affect customer customer experience. This is in line with the Stimulus-Organism-Response theory which states that the environment is a stimulus (S) consisting of a set of signs that causes a person's internal evaluation (O) and then produces a response (R) (Mehrabian \& Russell, 1974). This study reveals that there is a combination that is a determining factor in Islamic banking services or e-servicescape. This determining factor is a stimulus according to the S-O-R theory, namely Visual Attractiveness, Application Security, Entertainment Value, Originality of Design, Relevance of Information, Interactivity, Ease of Transaction and Usability. Based on the e-servicescape dimension, we can see that this is something that can improve the customer experience of banking customers.

Additionally, previous research has examined S-O-R frameworks in other electronic environments, such as online banking. Online applications usually use emotional experiences as states of organisms that lead to individual responses. However, Eroglu et al., (2003) show that emotional schemas do not capture many of the effects of atmospheric cues. Therefore, this study argues that the overall customer attitude towards the mobile banking application can be seen as a fluctuating cognitive and affective state with guidance from the mobile banking application environment. Supported by Eroglu et al. (2003), the study found that customer trust in e-servicescape serves as a strong mechanism that shapes customer perceptions of eservicescape into engagement behavior. Therefore, this study suggests that future research should consider the overall attitude of consumers as elements of organisms in the SO-R research framework.

The assessment that consumers like about e-servicescape will shape the evaluation of the preferred e-servicescape. This evaluation served as the main intermediary to shape their engagement with e-servicescape. Therefore, strong customer involvement in e-servicescape requires the development of good customer perceptions of their overall environment and associated evaluations. The results of this study reveal that after banking customers have good confidence in e-servicescape, then this will have an impact on customers' virtual word of mouth behavior in using Islamic banking eservicescape. 
Andriani, Setyorini, \& Shibghatalloh Investigating E-Servicescape Influence to Customer Response in Digital Islamic Banking

\section{Conclusion and Recommendation}

\subsection{Conclusion}

Based on the results of hypothesis testing, the results show that all dimensions of e-servicescape have a positive significant effect on eservicescape, e-servicescape has a positive significant effect on trust, and trust has a positive significant effect on customer virtual word-of-mouth. As the existing literature application-based internet development must pay attention to all dimensions contained in e-servicescape. This shows that all dimensions of e-servicescape play an important role in influencing customer responses are trust and virtual electronic word of mouth.

\subsection{Recommendation}

This research contributes both theoretically and practically. This study contributes theoretically in adding to the variety of research objects in the eservicescape concept, which is usually e-servicescape is more often used in online shopping research, but this research tries to apply the e-servicescape concept in the field of digital banking, especially in Islamic banking. In addition, expanding the use of SOR theory in the context of digital banking. The practical contribution that can be given from this research is that first, service providers should pay attention to visuals that are good, entertaining, informative, easy to read, and provide clear instructions for each menu. Second, implementing layered security to anticipate virtual crimes against the internet banking system to maintain customer confidence in transactions and provide clear information about the security and confidentiality guarantees provided by customers.

This study also have several limitation, the number of samples is too small so that future studies are expected to be able to increase the number of samples to get better geeralization results. This study only examines e-servicescape in the context of Islamic banking, so it is suggested that future studies also examine the context of conventional banking and then compare the both. This study only captures at customer responses in terms of virtual word-of-mouth, so it is suggested that future research can add other constructs as dependent constructs that can capture customer responses in other forms such as customer engagement. In addition, future research is suggested to test eservicescape in other financial technology contexts such as electronic money application services to increase the variety of findings related to eservicescape in the context of digital finance. 
Andriani, Setyorini, \& Shibghatalloh | Investigating E-Servicescape Influence to Customer Response in Digital Islamic Banking

\section{References}

Akturan, U., \& Tezcan, N. (2012). Mobile banking adoption of the youth market: Perceptions and intentions. Marketing Intelligence and Planning, 30(4), 444-459.

Baidhowi. (2018). Sharia banking opportunities and challenges in the digital era. Advances in Social Science, Education and Humanities Research, 192, 157-161.

Baptista, G., \& Oliveira, T. (2016). A weight and a meta-analysis on mobile banking acceptance research. Computers in Human Behavior, 63, 480489.

Bitner, M. J. (1992). Servicescapes: The impact of physical surroundings on customers and employees. Journal of Marketing, 56(2), 57. https://doi.org/10.2307/1252042

Brown, T. J., Mowen, J. C., Donavan, T. D., \& Licata, J. W. (1996). The customer orientation of service workers: Personality trait effects on self- and supervisor performance ratings. Journal of Marketing Reserach, XXXIX(February 2002), 110-119.

Chan, Y. Y. Y., \& Ngai, E. W. T. (2011). Conceptualising electronic word of mouth activity: An input-process-output perspective. Marketing Intelligence and Planning, 29(5), 488-516.

Cheung, C. M. K., Lee, M. K. O., \& Rabjohn, N. (2008). The impact of electronic word-of-mouth: The adoption of online opinions in online customer communities. Internet Research, 18(3), 229-247.

Cheung, C. M. K., \& Thadani, D. R. (2012). The impact of electronic word-ofmouth communication: A literature analysis and integrative model. Decision Support Systems, 54(1), 461-470.

Dailey, L. (2004). Navigational web atmospherics: Explaining the influence of restrictive navigation cues. Journal of Business Research, 57(7), 795803.

Donovan, R. J., \& Rossiter, J. R. (1982). An environmental psychology approach. Journal of Retailing, pp. 34-57.

Effendy, O. U. (2003). IImu, teori dan filsafat komunikasi. Bandung : Citra Aditya Bakti

Eroglu, S. A., Machleit, K. A., \& Davis, L. M. (2003). Empirical testing of a model of online store atmospherics and shopper responses. Psychology and Marketing, 20(2), 139-150. https://doi.org/10.1002/mar.10064

Ha, Y., \& Lennon, S. J. (2010). Online visual merchandising (VMD) cues and consumer pleasure and arousal: Purchasing versus browsing situation. Psychology \& Marketing, 27(2), 141-165.

Hair, J. F. J., Hult, G. T. M., Ringle, C., \& Sarstedt, M. (2014). A Primer on Partial Least Squares Structural Equation Modeling (PLS-SEM). Long Range Planning (Vol. 46) 
Andriani, Setyorini, \& Shibghatalloh | Investigating E-Servicescape Influence to Customer Response in Digital Islamic Banking

Harris, L. C., \& Goode, M. M. H. (2010). Online servicescapes, trust, and purchase intentions. Journal of Services Marketing, 24(3), 230-243. https://doi.org/10.1108/08876041011040631

Heinonen, K. (2004). Reconceptualizing customer perceived value: The value of time and place. Managing Service Quality: An International Journal, 14(2), 205-215. https://doi.org/10.1108/09604520410528626

Hennig-Thurau, T., Gwinner, K. P., Walsh, G., \& Gremler, D. D. (2004). Electronic word-of-mouth via consumer-opinion platforms: What motivates consumers to articulate themselves on the Internet? Journal of Interactive Marketing, 18(1), 38-52. https://doi.org/10.1002/dir.10073

Hung, K. H., \& Li, S. Y. (2007). The influence of eWOM on virtual consumer communities: Social capital, consumer learning, and behavioral outcomes. Journal of Advertising Research, Vol. 47. https://doi.org/10.2501/S002184990707050X

Ismagilova, E., Slade, E. L., Rana, N. P., \& Dwivedi, Y. K. (2020). The Effect of Electronic Word of Mouth Communications on Intention to Buy: A MetaAnalysis. Information Systems Frontiers, 22(5), 1203-1226. https://doi.org/10.1007/s10796-019-09924-y

Kamboj, S., Sarmah, B., Gupta, S., \& Dwivedi, Y. (2018). Examining branding co-creation in brand communities on social media: Applying the paradigm of Stimulus-Organism-Response. International Journal of Information Management, 39(December 2017), 169-185. https://doi.org/10.1016/j.ijinfomgt.2017.12.001

Katz, E., \& Lazarsfeld, P. F. (1966). Personal Influence, The part played by people in the flow of mass communications. Transaction Publishers.

Kawaf, F., \& Tagg, S. (2012). Online shopping environments in fashion shopping: An S-O-R based review. In The Marketing Review (Vol. 12). https://doi.org/10.1362/146934712×13366562572476

Kousaridas, A., Parissis, G., \& Apostolopoulos, T. (2008). An open financial services architecture based on the use of intelligent mobile devices. Electronic Commerce Research and Applications, 7(2), 232-246. https://doi.org/10.1016/j.elerap.2007.04.003

Lai, K. P., Chong, S. C., Ismail, H. Bin, \& Tong, D. Y. K. (2014). An explorative study of shopper-based salient e-servicescape attributes: A Means-End Chain approach. International Journal of Information Management, 34(4), 517-532. https://doi.org/10.1016/j.ijinfomgt.2014.01.010

Mallat, N. (2007). Exploring Consumer Adoption of Mobile Payments - A Qualitative Study. Working Papers on Information Systems, 6(2006).

Mari, M., \& Poggesi, S. (2013). Servicescape cues and customer behavior: a systematic literature review and research agenda. Service Industries Journal, 33(2), 171-199. https://doi.org/10.1080/02642069.2011.613934

Mayzlin, D., Dover, Y., \& Chevalier, J. (2014). Promotional reviews: An 
Andriani, Setyorini, \& Shibghatalloh | Investigating E-Servicescape Influence to Customer Response in Digital Islamic Banking

empirical investigation of online review manipulation. American Economic Review, 104(8), 2421-2455. https://doi.org/10.1257/aer.104.8.2421

Moser, A. K. (2015). Thinking green, buying green? Drivers of pro Environmental purchasing behavior. Journal of Consumer Marketing, 32(3), 167-175. https://doi.org/10.1108/JCM-10-2014-1179

Nazlan, N. H., Tanford, S., \& Montgomery, R. (2018). The effect of availability heuristics in online consumer reviews. Journal of Consumer Behaviour, 17(5), 449-460. https://doi.org/10.1002/cb.1731

Neuman, W. L. (2016). Understanding research. Pearson.

Papadopoulou, P., Andreou, A., Kanellis, P., \& Martakos, D. (2001). Trust and relationship building in electronic commerce. IInternet Research: Electronic Networking Applications and Policy, 11(4), 322-332.

Rao, S., \& Troshani, I. (2007). A conceptual framework and propositions for the acceptance of mobile services. Journal of Theoretical and Applied Electronic Commerce Research, 2(2), 61-73.

Reinartz, W., Haenlein, M., \& Henseler, J. (2009). An empirical comparison of the efficacy of covariance-based and variance-based SEM. International Journal of research in Marketing, 26(4), 332-344.

Ringle, C., Da Silva, D., \& Bido, D. (2015). Structural equation modeling with the SmartPLS. Bido, D., da Silva, D., \& Ringle, C.(2014). Structural Equation Modeling with the Smartpls. Brazilian Journal Of Marketing, 13(2).

Russell, J. A., \& Mehrabian, A. (1974). Distinguishing anger and anxiety in terms of emotional response factors. Journal of consulting and clinical psychology, 42(1), 79.

Sahoo, D., \& Pillai, S. S. (2017). Role of mobile banking servicescape on customer attitude and engagement: An empirical investigation in India. International Journal of Bank Marketing, 35, 1113-1130. Retrieved from https://doi.org/10.1108/IJBM-09-2015-0144

Tam, C., \& Oliveira, T. (2016). Performance impact of mobile banking: using the task-technology fit (TTF) approach. International Journal of Bank Marketing, 34(4), 434-457. https://doi.org/10.1108/IJBM-11-20140169

Tankovic, A. C., \& Benazic, D. (2018). The perception of e-servicescape and its influence on perceived e-shopping value and customer loyalty. Online Information Review, 42(7), 1124-1145. https://doi.org/10.1108/OIR-122016-0354

Tran, G. A., \& Strutton, D. (2020). Comparing email and SNS users: Investigating e-servicescape, customer reviews, trust, loyalty and EWOM. Journal of Retailing and Consumer Services, 53(April 2019), 101782. https://doi.org/10.1016/j.jretconser.2019.03.009

Trusov, M., Bucklin, R. E., \& Pauwels, K. (2009). Effects of Word of Mouth versus Traditional Marketing: Findings from an Internet Social 
Andriani, Setyorini, \& Shibghatalloh | Investigating E-Servicescape Influence to Customer Response in Digital Islamic Banking

Networking Site. Retrieved from https://eresearch.ozyegin.edu.tr/bitstream/handle/10679/56/Effects_ of_Word-of-

Mouth_Versus_Traditional_Marketing_Findings_from_an_Internet_So cial_Networking_Site.pdf?sequence=5\&isAllowed $=y$

Tsao, W. C., \& Hsieh, M. T. (2012). Exploring how relationship quality influences positive eWOM: The importance of customer commitment. Total Quality Management and Business Excellence, 23(7-8), 821-835. https://doi.org/10.1080/14783363.2012.661137

Tsiakis, T., \& Sthephanides, G. (2005). The concept of security and trust in electronic payments. Computers and Security, 24(1), 10-15. https://doi.org/10.1016/j.cose.2004.11.001

Turley, L. W., \& Milliman, R. E. (2000). Atmospheric effects on shopping behavior: A review of the experimental evidence. Journal of Business Research, 49(2), 193-211. https://doi.org/10.1016/s01482963(99)00010-7

Wessels, L., \& Drennan, J. (2010). An investigation of consumer acceptance of M-banking. International Journal of Bank Marketing, 28(7), 547-568. https://doi.org/10.1108/02652321011085194 
Andriani, Setyorini, \& Shibghatalloh | Investigating E-Servicescape Influence to Customer Response in Digital Islamic Banking

This page is intentionally left blank.

International Journal of Islamic Economics and Finance (IJIEF), 4(1), 101-120 | 120 